\author{
Agnieszka Orkusz, Agnieszka Wlodarczyk \\ Uniwersytet Ekonomiczny we Wrocławiu \\ e-mail: agnieszka.orkusz@ue.wroc.pl
}

\title{
OCENA ŻYWIENIA DZIECI W PRZEDSZKOLU NA PODSTAWIE DEKADOWYCH JADLOSPISÓW
}

\begin{abstract}
Streszczenie: Żywienie jest jednym z najważniejszych czynników warunkujących prawidłowy wzrost i rozwój dzieci. W żywieniu przedszkolnym powinno być realizowane $75 \%$ całodziennej racji pokarmowej. Celem pracy była ocena wartości energetycznej i odżywczej posiłków serwowanych w stołówce przedszkolnej w oparciu o teoretyczną analizę jadłospisów z zastosowaniem programu komputerowego Dieta 4D. Obliczono wartość energetyczną, zawartość: białka, tłuszczu, węglowodanów; witamin A i C oraz składników mineralnych: $\mathrm{Ca}$ i Fe dla 40 całodziennych jadłospisów przedszkolnych z czterech pór roku: wiosny, lata, jesieni i zimy. $\mathrm{W}$ badanych racjach pokarmowych uwidoczniły się nieprawidłowości związane ze zbyt dużym spożyciem energii, tłuszczów oraz węglowodanów w stosunku do normy. Poniżej normy w analizowanych jadłospisach przedszkolnych była zawartość wapnia i witaminy C. Powyżej normy w badanych racjach pokarmowych kształtowała się zawartość witaminy A. Sugeruje to konieczność edukacji pracowników przedszkola w zakresie prawidłowego żywienia dzieci.
\end{abstract}

Słowa kluczowe: jadłospis, żywienie dzieci, dzieci w wieku przedszkolnym, składniki odżywcze, zalecenia żywieniowe.

DOI: $10.15611 /$ nit.2014.1.05

\section{Wstęp}

Prawidłowe żywienie dzieci polega na dostarczeniu w kilku dziennych posiłkach wszystkich niezbędnych składników odżywczych w odpowiednich ilościach i proporcjach. Zbyt małe lub nadmierne spożycie energii i składników pokarmowych w tym okresie może uniemożliwić pełny rozwój psychofizyczny organizmu czy też zachowanie optymalnego stanu zdrowia. Dziecko spędza w przedszkolu ok. 6-7 godzin dziennie, stąd istotna jest jakość pożywienia, jakie otrzymuje ono w posiłkach. Należy pamiętać, że dzieci w okresie wzrostu wykazują szczególną wrażliwość na wszelkie niedobory pokarmowe powstające w tym czasie. Coraz więcej badań wskazuje, iż istnieje ścisły związek między stanem odżywienia w okresie dzieciństwa a zdrowiem człowieka dorosłego [Kozłowska-Wojciechowska, Makarewicz-Wujec 2005; Sochacka-Tatara i in. 2008]. 
Celem pracy było oszacowanie wartości odżywczej posiłków oraz ocena żywienia dzieci w jednym z przedszkoli w Wieluniu w oparciu o jadłospisy dekadowe w zależności od pory roku.

\section{Materiały i metody badawcze}

Badania polegały na ocenie jadłospisów pochodzących z jednego z przedszkoli znajdującego się w Wieluniu, w województwie łódzkim. Posiłki dla dzieci przygotowywane były w budynku przedszkola, na terenie którego znajduje się stołówka $\mathrm{z}$ dobrze wyposażoną kuchnią.

Wstępna analiza wykazała stosowanie w stołówce przedszkolnej dekadowego systemu układania jadłospisów. W związku z tym ocenie poddano po 10 całodziennych racji pokarmowych (losowo wybrana jedna dekada) z każdej pory roku.

Przeprowadzono ocenę 40 całodziennych jadłospisów. Jadłospisy pochodziły z roku 2011. Stosując tabele „Produkty spożywcze, skład i wartość odżywcza” oraz program komputerowy Dieta 4D (IŻ̇̇, Warszawa, wyd. III), wyznaczono wartość energetyczną oraz zawartość składników odżywczych, takich jak: białka, tłuszcze, węglowodany, składniki mineralne (wapń, żelazo) oraz witaminy (A, C) w jadłospisach 10-dniowych dla poszczególnych pór roku: wiosny, lata, jesieni i zimy. W obliczeniach uwzględniono straty związane ze stosowanymi procesami technologicznymi. Dla wartości energetycznej, białka ogółem, tłuszczów, węglowodanów, wapnia i żelaza zastosowano straty równe $10 \%$. Ze względu na zróżnicowaną wrażliwość witamin na czynniki występujące podczas obróbki kulinarnej potraw wartości dla witaminy A zredukowano o $20 \%$, dla witaminy C zaś o $55 \%$ [Kunachowicz i in. 2005; Orkusz, Przysiężna 2000]. Wartości spożycia różniące się o $\pm 10 \%$ od wartości norm przyjęto za prawidłowe.

W dalszej części pracy przyjęto określenie całodzienna racja pokarmowa (CRP), które oznacza posiłki serwowane wyłącznie w przedszkolu, tj. śniadanie, obiad i podwieczorek.

Do oceny sposobu żywienia dzieci w wieku 4-6 lat, o masie $19 \mathrm{~kg}$ i umiarkowanej aktywności fizycznej przyjęto zgodnie z normami dzienne zapotrzebowanie energetyczne $1400 \mathrm{kcal}$ (tab. 1). Za normę żywienia przedszkolnego przyjęto $75 \%$ dziennej normy na energię i składniki odżywcze zalecanej dla dzieci w wieku 4-6 lat [Cichocka 2011]. Do dalszej analizy przyjęto strukturę energii przedstawioną w tab. 1.

Przeprowadzono analizę statystyczną wyników, obliczono średnią arytmetyczną oraz odchylenie standardowe. Do zbadania istotnych różnic zawartości energii i składników pokarmowych w badanych jadłospisach, w zależności od pory roku, zastosowano analizę wariancji jednoczynnikową, na poziome istotności $p \leq 0,05$. 
Tabela 1. Struktura energii racji pokarmowej dla dzieci w wieku 4-6 lat o umiarkowanej aktywności fizycznej

\begin{tabular}{|l|c|c|c|}
\cline { 2 - 4 } \multicolumn{1}{c|}{} & \multicolumn{2}{|c|}{$\begin{array}{c}\text { Całodzienna racja pokarmowa } \\
\text { Energia: } 1400 \mathrm{kcal}\end{array}$} & $\begin{array}{c}\text { Wyżywienie przedszkolne - } \\
\text { ny całodziennego zapotrzebowania } \\
\text { Energia: } 1050 \text { kcal }\end{array}$ \\
\hline $\begin{array}{c}\text { Składniki } \\
\text { pokarmowe }\end{array}$ & $\begin{array}{c}\text { \% udziału w całodziennym } \\
\text { zapotrzebowaniu na energię }\end{array}$ & Ilość (g) & Ilość (g) \\
\hline Białko & $10-15$ & $35,0-52,5$ & $26,3-39,4$ \\
\hline Tłuszcze & $30-35$ & $47,0-54,5$ & $35,0-40,8$ \\
\hline Węglowodany & $55-65$ & $192,5-227,5$ & $144,4-170,6$ \\
\hline
\end{tabular}

Źródło: opracowanie własne na podstawie [Jarosz, Bułhak-Jachymczyk 2008].

\section{Wyniki i ich omówienie}

Analizowane jadłospisy planowane były na 10 dni. W ciągu tego okresu posiłki były skomponowane w sposób niepowtarzający się i urozmaicony, co podnosiło ich atrakcyjność. Planowanie zestawów żywieniowych na taki okres usprawniło organizację pracy przy sporządzaniu posiłków, jak i zaopatrzeniu oraz przechowywaniu produktów spożywczych.

Całodzienna racja pokarmowa w przedszkolu składała się z 3 posiłków: śniadania, obiadu oraz podwieczorka. Śniadanie było podawane o godzinie 9:00, obiad o 13:00, natomiast podwieczorek o 16:00. Odstępy między posiłkami były prawidłowe, wynosiły kolejno 4 i 3 godziny.

Przy założeniu, że dziecko w ciągu dnia spożywało w sumie 4 lub 5 posiłków (1 lub 2 zjadło w domu), procentowy rozkład energii na posiłki serwowane w przedszkolu był nieprawidłowy (tab. 2). Występował zbyt wysoki, w stosunku do zaleceń, udział energii w obiedzie (od 51,2\% do 54,1\%) i podwieczorku (od 22,0\% do $24,0 \%$ ) w każdej z pór roku.

Tabela 2. Procentowy rozkład energii na posiłki serwowane w przedszkolu w zależności od pory roku

\begin{tabular}{|l|c|c|c|c|}
\hline \multicolumn{1}{|c|}{ Nazwa posiłku } & Wiosna & Lato & Jesień & Zima \\
\hline Śniadanie & 24,8 & 23,9 & 24,1 & 25,0 \\
\hline Obiad & 51,2 & 54,1 & 53,9 & 51,9 \\
\hline Podwieczorek & 24,0 & 22,0 & 22,0 & 23,1 \\
\hline
\end{tabular}

Źródło: opracowanie własne.

$\mathrm{Na}$ śniadania podawano zwykle pieczywo z masłem oraz produktem wysokobiałkowym (wędliny, jaja, pasty z ryb, wędlin lub jaj). Serwowano również mleko z płatkami kukurydzianymi lub zbożowymi, kawę zbożową, kakao. Do każdego 
śniadania podawano owoce (najczęściej jabłka, banany, a w okresie letnim jagody, truskawki) lub warzywa (ogórki, rzodkiewki, pomidory, zieloną sałatę, szczypiorek).

Obiad składał się zawsze z dwóch dań: zupy oraz drugiego dania. Serwowano m.in. zupę: pomidorową, ziemniaczaną, botwinkę, krupnik, rosół, kapuśniak. Zupy przygotowywane były na bazie wywaru mięsno-warzywnego, a w okresie wiosenno-letnim wzbogacane były świeżym koperkiem lub natką pietruszki.

$\mathrm{Na}$ drugie danie serwowano produkty będące źródłem pełnowartościowego białka, m.in.: mięso, drób, ryby, które uzupełniano produktami bogatymi w węglowodany (ziemniaki, makarony, kasze, kluski, ryż). Owoce i warzywa podawano zazwyczaj w postaci surowej. Do obiadu podawany był zwykle kompot z owoców mieszanych.

Podwieczorek składał się najczęściej z produktów bogatych w węglowodany (drożdżówki, kisiel, pieczywo z masłem czekoladowym, miodem) oraz z ciepłego napoju (herbata, mleko, napoje mleczne). Czasami serwowano kanapki (z pasztetem, polędwicą, kiełbasą).

Posiłki były przygotowywane różnymi technikami - produkty były smażone, gotowane, duszone i pieczone. Różnorodność sposobów przyrządzania potraw umożliwiała uzyskanie różnych wariantów potraw przygotowanych z tych samych produktów spożywczych.

Posiłki były apetyczne, skomponowane w sposób kontrastowy pod względem smaku, zapachu oraz barwy, zachęcające dzieci do konsumpcji. Podczas jednego posiłku wystrzegano się zestawiania dwóch potraw o podobnym charakterze (słodkim, kwaśnym czy podobnej barwie i konsystencji). Do minimum ograniczono stosowanie soli, octu oraz maggi. Zastąpiono je ziołami (bazylia, kminek, majeranek), które ułatwiają przyswajalność i strawność potraw.

W jadłospisach zauważalna była sezonowość produktów. Latem podawano świeże warzywa, np.: ogórki, pomidory, zieloną sałatę, szczypiorek i paprykę oraz sezonowe owoce - truskawki i jagody. Natomiast zimą serwowano gotowane warzywa, kiszoną kapustę, ogórki kwaszone, a z owoców: jabłka, gruszki i banany.

Wadą analizowanych jadłospisów był brak wykorzystania nasion roślin strączkowych, które stanowią dobre źródło białka, błonnika pokarmowego, węglowodanów, witamin z grupy B oraz składników mineralnych: żelaza, miedzi, wapnia, magnezu, manganu, potasu, cynku i siarki.

Wartość energetyczna posiłków serwowanych w przedszkolu wahała się od 1298,9 kcal latem do 1368,7 kcal zimą (tab. 3). Mimo że w analizowanych jadłospisach przedszkolnych nie zauważono istotnych różnic wartości energetycznej posiłków ze względu na porę roku, to zaobserwowano korzystną tendencję wzrostu energii $\mathrm{w}$ jadłospisach $\mathrm{w}$ okresie zimowym, kiedy to rosną wydatki energetyczne organizmu związane $\mathrm{z}$ koniecznością utrzymania temperatury ciała na poziomie ok. $37^{\circ} \mathrm{C}$, przy jednoczesnym spadku temperatury otoczenia. Podobne zjawisko odnotowały Orkusz i Przysiężna [2000] w jadłospisach obiadowych serwowanych w stołówce studenckiej. 
Analiza uzyskanych wyników (tab. 3) wykazała, iż wartość energetyczna badanych jadłospisów była nieprawidłowa. Jadłospisy pokrywały zapotrzebowanie na energię w ilości większej niż 75\% normy, czyli zapotrzebowania w żywieniu przedszkolnym.

Tabela 3. Wartość energetyczna i zawartość składników odżywczych w jadłospisach przedszkolnych w zależności od pory roku

\begin{tabular}{|c|c|c|c|c|c|c|c|c|c|}
\hline \multirow[b]{2}{*}{$\begin{array}{c}\text { Energia } \\
\text { i składniki } \\
\text { odżywcze }\end{array}$} & \multirow{2}{*}{$\begin{array}{c}75 \% \\
\text { zapotrze- } \\
\text { bowania } \\
\text { dziennego }\end{array}$} & \multicolumn{2}{|c|}{ Wiosna } & \multicolumn{2}{|c|}{ Lato } & \multicolumn{2}{|c|}{ Jesień } & \multicolumn{2}{|c|}{ Zima } \\
\hline & & $\begin{array}{c}\mathrm{x} \\
\pm \mathrm{SD}\end{array}$ & $\begin{array}{c}\% \\
\text { realizacji } \\
\text { normy }\end{array}$ & $\begin{array}{c}\mathrm{x} \\
\pm \mathrm{SD}\end{array}$ & $\begin{array}{c}\% \\
\text { realizacji } \\
\text { normy }\end{array}$ & $\begin{array}{c}\mathrm{x} \\
\pm \mathrm{SD}\end{array}$ & $\begin{array}{c}\% \\
\text { realizacji } \\
\text { normy }\end{array}$ & $\begin{array}{c}\mathrm{x} \\
\pm \mathrm{SD}\end{array}$ & $\begin{array}{c}\% \\
\text { realizacji } \\
\text { normy }\end{array}$ \\
\hline \multirow{2}{*}{$\begin{array}{l}\text { Wartość } \\
\text { energetyczna (kcal) }\end{array}$} & \multirow[t]{2}{*}{1050} & 1359,2 & 129,4 & 1298,9 & 123,7 & 1327,5 & 126,4 & 1368,7 & 130,4 \\
\hline & & $\pm 110,0$ & & $\pm 86,1$ & & $\pm 79,5$ & & $\pm 64,1$ & \\
\hline \multirow{2}{*}{ Białko ogółem (g) } & \multirow[t]{2}{*}{39,4} & 42,0 & 106,7 & 38,5 & 97,8 & 35,6 & 90,5 & 39,9 & 101,2 \\
\hline & & $\pm 6,9$ & & $\pm 5,8$ & & \pm 4.0 & & $\pm 5,2$ & \\
\hline \multirow{2}{*}{ Tłuszcz (g) } & \multirow[t]{2}{*}{40,90} & 49,8 & 121,7 & 48,3 & 118,2 & 45,7 & 111,8 & 54,0 & 132,0 \\
\hline & & $\pm 6,0$ & & $\pm 6,1$ & & $\pm 6,4$ & & $\pm 4,5$ & \\
\hline \multirow{2}{*}{ Węglowodany (g) } & \multirow[t]{2}{*}{144,4} & 186,2 & 128,9 & 177,8 & 123,1 & 193,1 & 133,8 & 180,4 & 124,9 \\
\hline & & $\pm 12,9$ & & $\pm 10,2$ & & $\pm 14,5$ & & $\pm 10,0$ & \\
\hline \multirow{2}{*}{ Wapń (mg) } & \multirow[t]{2}{*}{525} & 379,8 & 72,3 & 382,5 & 72,9 & 352,8 & 67,2 & 411,1 & 78,3 \\
\hline & & $\pm 56,5$ & & $\pm 64,2$ & & $\pm 49,9$ & & $\pm 54,1$ & \\
\hline \multirow{2}{*}{ Żelazo (mg) } & \multirow[t]{2}{*}{7,5} & 7,5 & 99,9 & 7,7 & 103,2 & 7,4 & 99,2 & 7,8 & 104,4 \\
\hline & & $\pm 1,2$ & & $\pm 1,9$ & & $\pm 1,4$ & & $\pm 1,3$ & \\
\hline \multirow{2}{*}{ Witamina A $(\mu \mathrm{g})$} & \multirow[t]{2}{*}{337,5} & 421,3 & 124,8 & 455,4 & 134,9 & 415,1 & 123,0 & 487,1 & 144,3 \\
\hline & & $\pm 77,3$ & & $\pm 53,3$ & & $\pm 39,5$ & & $\pm 67,2$ & \\
\hline \multirow{2}{*}{ Witamina C (mg) } & \multirow[t]{2}{*}{37,5} & $25,9^{\mathrm{a}}$ & 69,1 & $44,2^{\mathrm{b}}$ & 117,8 & $30,4^{\mathrm{a}}$ & 81,0 & $28,5^{\mathrm{a}}$ & 76,1 \\
\hline & & $\pm 4,3$ & & $\pm 3,8$ & & $\pm 4,0$ & & $\pm 3,7$ & \\
\hline
\end{tabular}

Objaśnienia: x - wartość średnia z 10 jadłospisów; SD - odchylenie standardów; różnice między wartościami średnimi oznaczonymi różnymi literami są statystycznie istotne $(p \leq 0,05)$.

Źródło: opracowanie własne.

W strukturze energii analizowanych jadłospisów nie stwierdzono istotnych różnic w zależności od pory roku (tab. 4). Odnotowano mieszczący się w granicach normy udział energii pochodzącej z białek (10,7\%-12,3\%), tłuszczów (31,1\%-35,50\%) oraz węglowodanów $(54,7 \%-58,2 \%)$ z wyjątkiem sezonu zimowego. W okresie tym odsetek wartości energetycznej pochodzącej z węglowodanów plasował się poniżej obowiązującej normy dla dzieci w wieku 4-6 lat.

Całkowita zawartość białka w analizowanych jadłospisach przedszkolnych nie różniła się istotnie w zależności od pory roku i mieściła się w granicach zalecanej normy w każdej z pór roku (tab. 3). Prawidłowa zawartość białka ma duże znaczenie przy stwierdzonej w badanych jadłospisach zbyt niskiej podaży wapnia (tab. 3), ponieważ dieta bogatobiałkowa sprzyja wydalaniu wapnia z moczem. 
Tabela 4. Procentowy udział energii z białek, tłuszczów i węglowodanów w jadłospisach przedszkolnych w zależności od pory roku

\begin{tabular}{|l|c|c|c|c|}
\hline \multicolumn{1}{|c|}{ Udział energii z: } & Wiosna & Lato & Jesień & Zima \\
\hline Białek & 12,3 & 11,8 & 10,7 & 11,8 \\
\hline Tłuszczów & 32,9 & 33,5 & 31,1 & 35,5 \\
\hline Węglowodanów & 54,8 & 54,7 & 58,2 & 52,7 \\
\hline
\end{tabular}

Źródło: opracowanie własne.

Zawartość tłuszczów w analizowanych jadłospisach nie różniła się w zależności od pory roku (tab. 3). Podobnie jak w przypadku wartości energetycznej analizowanych jadłospisów, stwierdzono tendencję do zwiększania zawartości tłuszczów w posiłkach serwowanych zimą. Dzieciom w wieku 4-6 lat o masie ciała $19 \mathrm{~kg}$ oraz umiarkowanej aktywności fizycznej zaleca się spożywanie tłuszczu w ilości do $54,5 \mathrm{~g}$, z czego 35,0-40,8 g powinny dostarczać posiłki przedszkolne (tab. 1). Zawartość tłuszczów ogółem w analizowanych racjach pokarmowych była zbyt wysoka, wahała się od 45,7 g jesienią do $54 \mathrm{~g}$ zimą (tab. 3). Zbyt duża zawartość tłuszczu w żywieniu człowieka wpływa na powstanie miażdżycy, a także przyczynia się do rozwoju niektórych schorzeń nowotworowych [Ciborowska 2009]. Należy zwrócić uwagę, iż przy nadmiarze tłuszczów zmniejsza się absorpcja wapnia, którego zawartość $\mathrm{w}$ analizowanych racjach pokarmowych i tak była za niska w stosunku do zalecanych norm. Grajeta i in. [2003] oraz Kowieska i in. [2009] odnotowali również zbyt wysoką podaż tłuszczu w posiłkach przedszkolnych.

Zawartość węglowodanów w analizowanych racjach pokarmowych nie różniła się istotnie w zależności od pory roku i wahała się od 177,8 g latem do 193,1 g jesienią (tab. 3). Z porównania uzyskanych wyników do zaleceń spożycia węglowodanów wynika, że zawartość węglowodanów w analizowanych racjach pokarmowych powinna być zmniejszona. Niepokojący ich nadmiar w diecie dzieci w wieku przedszkolnym potwierdzają również wyniki badań: Czech i Kęski [2007], Dymkowskiej-Malesy i Skibniewskiej [2011], Kłos i Bertrandta [1999] oraz Kowieski i in. [2009]. Bagińska i Stokowska [2006] wykazały, iż nadmierna podaż cukrów u badanej populacji może być przyczyną próchnicy w tym wieku, a w późniejszym okresie przyczynić się do otyłości.

Zawartość składników mineralnych: wapnia i żelaza oraz witaminy A nie różniła się istotnie w zależności od pory roku (tab. 3). Analizowane jadłospisy w różnym stopniu, w stosunku do zalecanych norm, pokrywały zapotrzebowanie dzieci na wapń, żelazo, witaminę A i C. Poniżej normy w analizowanych racjach pokarmowych była zawartość zarówno wapnia w każdej z pór roku, jak i witaminy $\mathrm{C}$ w okresie jesienno-zimowym i wiosną.

Zapotrzebowanie na wapń zostało pokryte w wysokości od $67,2 \%$ jesienią do 78,3\% zimą (tab. 3). Zbyt mała zawartość wapnia w diecie jest zjawiskiem niekorzystnym, szczególnie niebezpiecznym dla dzieci, ponieważ przy niedoborach po- 
karmowych wapnia jego uzupełnianie odbywa się kosztem tkanki kostnej, powodując zwiększenie tempa spadku gęstości masy kostnej [Marcinowska-Suchowierska 2001]. Może to prowadzić m.in. do: zniekształceń kręgosłupa, odwapnienia organizmu, uszkodzeń zębów oraz zwiększać ryzyko zmian osteoporotycznych w wieku późniejszym [Król i in. 2005; Sochacka-Tatara i in. 2008]. Niedobór wapnia w diecie wpływa także na rozwój chorób układu sercowo-naczyniowego [Bolesławska i in. 2009]. Zbyt małe spożycie wapnia może również zwiększać ryzyko udaru mózgu u kobiet w średnim wieku [Elders i in. 1994].

Inni autorzy również informują o niewystarczającej ilości wapnia w dietach dzieci [Charzewska, Weker 2006; Klemarczyk i in. 2005; Kozioł-Kozakowska, Schlegel-Zawadzka 2007; Sochacka-Tatara i in. 2008], młodzieży [Leszczynska i in. 2005; Przysiężna i in. 2002] oraz dorosłych [Król i in. 2005; Leszczyńska, Bieżanowska-Kopeć 2005]. Jak donoszą Przysiężna i in. [2002], zbyt małą podaż wapnia stwierdza się w żywieniu różnych grup ludności, bez względu na sposób oznaczania, analitycznie czy obliczeniowo, jak też bez względu na materiał stanowiący podstawę oceny zawartości tego składnika mineralnego, czy są to wywiady żywieniowe, raporty magazynowe, czy też racje pokarmowe odtworzone w laboratorium.

Analizowane racje pokarmowe dostarczały witaminy $\mathrm{C}$ w ilości od $25,9 \mathrm{mg}$ wiosną do 44,2 mg latem i różniły się istotnie w zależności od pory roku (tab. 3). Najwyższą ilość kwasu askorbinowego odnotowano w badanych jadłospisach w okresie letnim, stwierdzając w nich równocześnie najwyższą podaż warzyw i owoców bogatych $\mathrm{w}$ witaminę $\mathrm{C}$ (tab. 5). W analizowanych jadłospisach zaobserwowano niekorzystną tendencję, jaką była niska zawartość witaminy $\mathrm{C} w$ jadłospisach w okresie jesienno-zimowym i wiosną, kiedy to szczególnie ważna jest odpowiednia podaż tej witaminy. Działa ona na system odpornościowy organizmu człowieka, biorąc udział w tworzeniu przeciwciał zwalczających wirusy i bakterie. Wiadomo również, iż niedobory witaminy C potęgują powstawanie zmian miażdżycowych [Grajek 2004; Orkusz, Przysiężna 2000; Stefańska i in. 2009]. Witaminy antyoksydacyjne, w tym witamina C, ograniczają także ryzyko chorób nowotworowych [Grajek 2004].

Zawartość żelaza $\mathrm{w}$ badanych racjach pokarmowych wynosiła od 7,4 mg jesienią do 7,8 mg zimą - przy zalecanej normie 7,5 $\mathrm{mg}$ (tab. 3).

Powyżej normy w analizowanych jadłospisach przedszkolnych kształtowała się zawartość witaminy A. Zawartość witaminy A wynosiła od $415,1 \mu \mathrm{g}$ jesienią do $487,1 \mu \mathrm{g}$ zimą, wartości te stanowiły odpowiednio $123,0 \%$ i $144,3 \%$ zalecanej normy (tab. 3). Nadmiar witaminy A jest toksyczny dla organizmu, może przejawiać się drażliwością, bólem głowy, wymiotami, krwawieniami dziąseł i zmianami skórnym. Duże dawki witaminy A powodują utratę wapnia z kości, co prowadzi m.in. do redukcji gęstości kości i łatwości ich złamań, a w następstwie do osteoporozy [Peckenpaugh 2011].

Odchylenia od norm spożycia składników mineralnych mogą wskazywać na istniejące ryzyko ich niedoborów oraz związane $\mathrm{z}$ tym konsekwencje $\mathrm{w}$ funkcjonowaniu organizmu dzieci oraz w późniejszych okresach ich życia. Zaobserwowane odchylenia mogą być niebezpieczne z tego względu, że oszacowano zawartość składników mineralnych w jadłospisach, a faktyczne ich spożycie może być niższe. 
Skorygowanie nieprawidłowości zaobserwowanych w analizowanych jadłospisach przedszkolnych można osiągnąć przez edukację osób odpowiedzialnych za żywienie dzieci.

Analizując zawartość grup produktów spożywczych w badanych jadłospisach przedszkolnych $\mathrm{w}$ zależności od pory roku, stwierdzono istotne różnice $\mathrm{w}$ grupie inne tłuszcze, masło oraz warzywa i owoce bogate w witaminę $\mathrm{C}$ (tab. 5). Jesienią, w porównaniu do pozostałych pór roku, odnotowano najwyższą podaż masła przy jednoczesnej najniższej podaży grupy inne tłuszcze. Latem, w porównaniu do pozostałych pór roku, serwowano najwięcej owoców i warzyw bogatych w witaminę C.

Wyniki uzyskane z analizy jadłospisów obiadowych wskazują na konieczność zwiększenia w pozostałych porach roku ilości świeżych warzyw i owoców bogatych w witaminę C, np. kapusty kiszonej, kapusty włoskiej i pomarańczy, oraz wzbogacenie posiłków w nasiona roślin strączkowych.

Tabela 5. Zawartość produktów spożywczych z poszczególnych grup produktów w analizowanych jadłospisach przedszkolnych w zależności od pory roku (g)

\begin{tabular}{|l|r|r|r|r|r|r|r|r|}
\hline \multirow{2}{*}{ Grupy produktów spożywczych } & \multicolumn{2}{|c|}{ Wiosna } & \multicolumn{2}{c|}{ Lato } & \multicolumn{2}{c|}{ Jesień } & \multicolumn{2}{c|}{ Zima } \\
\cline { 2 - 9 } & \multicolumn{1}{c|}{$\mathrm{x}$} & \multicolumn{1}{c|}{$\mathrm{SD}$} & \multicolumn{1}{c|}{$\mathrm{x}$} & \multicolumn{1}{c|}{$\mathrm{SD}$} & \multicolumn{1}{c|}{$\mathrm{x}$} & \multicolumn{1}{c|}{ SD } & \multicolumn{1}{c|}{$\mathrm{x}$} & \multicolumn{1}{c|}{ SD } \\
\hline Produkty zbożowe & 134,3 & 16,1 & 127,2 & 14,0 & 124,0 & 13,5 & 123,6 & 13,2 \\
\hline Mleko i produkty mleczne & 250,8 & 62,9 & 237,5 & 57,6 & 212,2 & 41,6 & 228,7 & 45,6 \\
\hline Jaja & 17,4 & 4,2 & 14,6 & 2,2 & 13,1 & 7,7 & 15,0 & 2,9 \\
\hline Mięso, wędliny i ryby & 95,9 & 27,4 & 102,3 & 23,9 & 91,1 & 34,5 & 102,8 & 20,7 \\
\hline Masło & $13,5^{\mathrm{a}}$ & 4,4 & $14,9^{\mathrm{a}}$ & 2,3 & $27,7^{\mathrm{b}}$ & 4,4 & $13,7^{\mathrm{a}}$ & 3,2 \\
\hline Inne tłuszcze & $20,6^{\mathrm{a}}$ & 3,8 & $20,4^{\mathrm{a}}$ & 2,4 & $15,5^{\mathrm{b}}$ & 2,6 & $22,0^{\mathrm{a}}$ & 2,5 \\
\hline Ziemniaki & 158,9 & 28,0 & 144,6 & 27,0 & 163,2 & 46,0 & 168,0 & 28,8 \\
\hline Warzywa i owoce (witamina C) & $27,6^{\mathrm{a}}$ & 8,2 & $132,9^{\mathrm{d}}$ & 26,7 & $84,0^{\mathrm{c}}$ & 16,4 & $54,1^{\mathrm{b}}$ & 15,5 \\
\hline Warzywa i owoce (karoten) & 52,7 & 4,5 & 78,8 & 18,6 & 51,4 & 23,1 & 64,5 & 20,3 \\
\hline Inne warzywa i owoce & 266,2 & 32,0 & 243,7 & 54,7 & 266,2 & 49,1 & 254,1 & 29,6 \\
\hline Strączkowe suche & - & - & - & - & - & - & - & - \\
\hline Cukier & 47,8 & 3,61 & 42,78 & 7,1 & 44,56 & 5,86 & 42,62 & 6,56 \\
\hline
\end{tabular}

Objaśnienia: $\mathrm{x}$ - wartość średnia z 10 jadłospisów; SD - odchylenie standardowe; różnice między wartościami średnimi oznaczonymi różnymi literami są statystycznie istotne $(p \leq 0,05)$.

Źródło: opracowanie własne.

\section{Wnioski}

1. W badanych jadłospisach stwierdzono nieprawidłowości w sposobie żywienia dzieci w przedszkolu w zakresie zbyt wysokiego w stosunku do zalecanych norm spożycia energii oraz tłuszczów i węglowodanów.

2. Analizowane jadłospisy w różnym stopniu zaspokajały zapotrzebowanie dzieci na witaminę A i C oraz składniki mineralne - wapń i żelazo: 
- poniżej normy w analizowanych jadłospisach przedszkolnych była zawartość wapnia oraz witaminy $\mathrm{C}$ w okresie jesienno-zimowym i wiosną;

- powyżej normy w badanych racjach pokarmowych kształtowała się zawartość witaminy A;

- jedynie zawartość żelaza była zgodna z obowiązującymi zaleceniami żywieniowymi dla tej grupy wiekowej.

3. Analiza jakościowa jadłospisów przedszkolnych wykazała, że były one układane zgodnie z zachowaniem zasad racjonalnego żywienia (różnorodna technika przyrządzania potraw, urozmaicenie, sezonowość produktów). Wadą badanych jadłospisów był brak wykorzystania nasion roślin strączkowych.

4. Przeprowadzona ocena przedszkolnych racji pokarmowych wskazuje na konieczność modyfikacji ich składu oraz edukację osób odpowiedzialnych za żywienie dzieci.

\section{Literatura}

Bagińska J., Stokowska W., Nawyki żywieniowe a intensywność próchnicy wczesnej u matych dzieci, „Wiad. Lek.” 2006, 59, s. 1-2, 5-9.

Bolesławska I., Przysławski J., Schlegel-Zawadzka M., Grzymisławski M., Zawartość składników mineralnych $w$ całodziennych racjach pokarmowych kobiet i mężczyzn stosujacych dietę tradycyjna i „optymalnq” - analiza porównawcza, „Żywność. Nauka. Technologia. Jakość” 2009, 4 (65), s. 303-311.

Charzewska J., Weker H., Ogólnopolskie badanie nad zawartościa wapnia i witaminy $D w$ dietach dzieci w wieku 4 lat, „Pediatria Współczesna” 2006, 8 (2), s. 107-109.

Ciborowska H., Sktadniki odżywcze i ich znaczenie w żywieniu, [w:] Dietetyka. Żywienie zdrowego $i$ chorego czlowieka, PZWL, Warszawa 2009, s. 85.

Cichocka A., Przyktadowe jadłospisy na 10 dni dla dzieci w wieku 4-6 lat; śniadanie - obiad - podwieczorek ( $1050 \mathrm{kcal}, 75 \%$ dziennego zapotrzebowania), [w:] Jadtospisy dla dzieci w wieku przedszkolnym (śniadania, obiady, podwieczorki) opracowane zgodnie z zasadami prawidłowego żywienia, red. J. Charzewska, Wyd. IŻŻ, Warszawa 2011, s. 131-157.

Czech A., Kęska A., Zawartość składników pokarmowych w racjach przedszkolnych w okresie wiosennym i jesiennym, „Żyw. Człow. Metab.” 2007, 34, s. 561-571.

Dymkowska-Malesa M., Skibniewska K.A., Udziat posiłków przedszkolnych w pokryciu zapotrzebowania na podstawowe sktadniki odżywcze i energie, „Bromat. Chem. Toksykol.” 2011, 44, 3, s. 374-379.

Elders P.J., Lips P., Netelenbos J.C., Van Ginkel F.C, Khoe E, Van der Vijgh W.J., Van der Stelt P.F., Long-term effect of calcium supplementation on bone loss in perimenopausal women, "J. Bone Miner. Res." 1994, 9, s. 963-970.

Grajek W., Rola przeciwutleniaczy w zmniejszaniu ryzyka wystapienia nowotworów i chorób układu krążenia, „Żywność. Nauka. Technologia. Jakość” 2004, 1 (38), s. 3-11.

Grajeta H., Ilow R., Prescha A., Regulska-Ilow B., Biernat J., Ocena wartości energetycznej i odżywczej positków przedszkolnych, Roczn. PZH 2003, 54, 4, s. 417-425.

Jarosz M., Bułhak-Jachymczyk B., Normy żywienia człowieka. Podstawowy prewencji otyłości i chorób niezakaźnych, Wyd. PZWL, Warszawa 2008. 
Klemarczyk W., Strucińska M., Weker H., Więch M., Ocena sposobu żywienia dzieci w przedszkolu wegetariańskim, „Pediatria Współczesna. Gastroenterologia. Hepatologia i Żywienie Dziecka” 2005, 7, 3, s. 243-246.

Kłos A., Bertrand J., Żywienie dzieci w wybranych przedszkolach wojskowych na terenie Warszawy, „Lekarz Wojskowy” 1999, 5, 6, s. 275-279.

Kowieska A., Biel W., Chalaba A., Charakterystyka żywienia dzieci w wieku przedszkolnym, „Żyw. Człow. Metab." 2009, 36, 1, s. 179-184.

Kozioł-Kozakowska A., Schlegel-Zawadzka M., Jakościowa ocena jadłospisów przedszkolnych w regionie Krakowa, „Żyw. Człow. Metab.” 2007, 34, 1-2, s. 133-138.

Kozłowska-Wojciechowska M., Makarewicz-Wujec M., Badanie preferencji żywieniowych dzieci $w$ wieku przedszkolnym, Roczn. PZH 2005, 2 (56), s. 165-169.

Król E., Sobiech M., Krejpcio Z., Ocena spożycia składników mineralnych w całodziennych racjach pokarmowych wybranej grupy wegetarian i niewegetarian, „Żywność. Nauka. Technologia. Jakość" 2005, 2 (43), Supl., 114-120.

Kunachowicz H., Nadolna I., Przygoda B., Iwanow K., Tabele składu i wartości odżywczej żywności, PZWL, Warszawa 2005, s. 13.

Leszczyńska T., Bieżanowska-Kopeć R., Ocena sposobu żywienia w gospodarstwach domowych prowadzonych przez osoby z wyższym wykształceniem, „Żywność. Nauka. Technologia. Jakość” 2005,4 (45), Supl., s. 151-161.

Leszczyńska T., Kapusta J., Pysz M., Ocena sposobu żywienia ludności wybranych gospodarstw wiejskich, „Żywność. Nauka. Technologia. Jakość” 2005, 4 (45), Supl., s. 162-176.

Marcinowska-Suchowierska E., Miejsce wapnia $i$ witaminy D, „Przew. Lek.” 2001, 4, 4, s. 34-41.

Orkusz A., Przysiężna E., Ocena wartości odżywczej positków obiadowych w stołówce studenckiej, „Żywność. Nauka. Technologia. Jakość” 2000, 4 (25), s. 122-132.

Peckenpaugh N.J., Podstawy żywienia i dietoterapia, red. wyd. polskiego D. Gajewska. Elsevier Urban \& Partner, Wrocław 2011, s. 88-93.

Przysiężna E., Klisz P., Orkusz A., Oszacowanie zawartości składników mineralnych w racjach pokarmowych młodzieży szkolnej, Żywność. Nauka. Technologia. Jakość” 2002, 1 (30), s. 132-140.

Sochacka-Tatara E., Jacek R., Sowa A., Musiał A., Ocena sposobu żywienia dzieci w wieku przedszkolnym, „Probl. Hig. Epidemiol.” 2008, 89 (3), s. 389-394.

Stefańska E., Ostrowska L., Czapska D., Karczewski J., Ocena zawartości witamin w całodziennych racjach pokarmowych kobiet o prawidłowej masie ciała oraz z nadwaga i otyłościa, „Żywność. Nauka. Technologia. Jakość” 2009, 4 (65), s. 286-294.

\section{ASSESSMENT OF PRESCHOOL CHILDREN'S DECADES MENUS}

Summary: Nutrition is one of the most important factors assuring normal growth and development of children. Kindergarten's meals should realise $75 \%$ of recommended daily allowances. The aim of this study is the energetic and nutritional evaluation of meals served in the kindergarten based on theoretical analysis of the menus using the Diet 4D computer program. The energy values, contents of protein, fat, carbohydrates, vitamins: A, C, mineral ingredients: $\mathrm{Ca}, \mathrm{Fe}$ were calculated for forty kindergarten menus of four seasons: spring, summer, autumn and winter. In the rations incorrectness was found connected with excessive - due to the norms - consumption of energy, fats and carbohydrates. The deficient intake in relation to the standards was observed for calcium and vitamin C. High dietary content of vitamin A was found. The results indicate the need for nutritional education for the kindergarten staff.

Keywords: menu, children nutrition, preschool children, nutrients, foods recommendations. 